\title{
THE MUNICIPAL BUDGETARY RESPONSE TO CHANGING LABOR COSTS: THE CASE OF SAN FRANCISCO
}

\author{
HARRY C. KATZ
}

A CADEMIC literature on the topic of budgeting in public agencies is sharply divided into two schools of thought -that focusing on the "organizational" (or bureaucratic) model and that focusing on the "demands" (or expenditure) model. The organizational model looks at budgetary expenditures as an outcome of a bureaucratic process, involving factors such as standard operating procedures and rules of thumb. The demands model, on the other hand, places the determination of public expenditures in an economic framework, often based on the assumption that voter preferences determine expenditure deci-

This paper analyzes how expenditures of the city of San Francisco were altered in response to changes in municipal labor costs over the period 1945 through 1976. A hybrid of the "demands" and the "organizational" models of budgeting is used to measure the budgetary response to changes in the relative prices of labor inputs. Descriptive and econometric evidence reveals significant adjustments both among and within departments in reaction to changes in relative labor costs. The empirical evidence demonstrates that the city's budgetary process is guided by simple allocative rules modified by price-responsive adjustments.

Harry C. Katz is Assistant Professor of Economics and Management at Massachusetts Institute of Technology. He is grateful to Michael Wiseman, Mark Kamlet, Henry Farber, Bennett Harrison, and members of the Harvard Labor Workshop for helpful sug. gestions. Financial support for this research was provided by a Department of Labor grant, but the author is solely responsible for the contents of the paper.EDITOR sions. Working with the latter model, it becomes possible to speak of income and price elasticities of the demand for public services.

This paper uses a hybrid of those two models to analyze how the budget of the city and county of San Francisco changed in the post-World War II period in response to changes in municipal labor costs. ${ }^{1}$ We rely heavily on the organizational model as a framework for the analysis and assert that budgetary allocations are largely a function of simple rules of thumb, which can be approximated by a constant shares decision rule. Departments are said to receive roughly a constant share of the increase in the total city budget and, within departments, labor's share also tends to be set as a constant fraction of total department expenditures. Price effects enter the model, however, as a factor that causes some readjustments in the allocation of department shares of the total city budget and labor's share of the expenditures of individual departments. Although basically relying on simple rules to guide their decisions, this model's decision makers adjust their rules in response to changes in the absolute and relative prices of inputs.

The model is tested utilizing budgetary appropriations of the city of San Francisco

\footnotetext{
${ }^{1}$ San Francisco is incorporated as a city and county; throughout this paper reference will be to the city of San Francisco.
} 
from $1945-76$. Large absolute and relative changes occurred in the wages and pensions received by various municipal employee groups in San Francisco in the post-World War II period. ${ }^{2}$ In particular, the wages and pensions of police officers, firefighters, transit drivers, and craft workers rose rapidly relative to both the consumer price index and the wages and pensions of other "miscellaneous" city employees. ${ }^{3}$ For example, from 1945 to 1976 the dollar base salary and pension costs of general laborers (a representative craft job title), police officers, firefighters, and transit drivers increased, respectively, $771,921,887$, and 769 percent. Over the same period the base salary and pension costs of clerk typists and assistant engineers (two representative miscellaneous employee job titles) increased 339 and 356 percent, respectively. On average, the pay increases received by police officers, firefighters, transit drivers, and craft workers were two to two and a half times greater than those received by miscellaneous employees over the post-World War II period.

Both the wages and pensions of San Francisco municipal employees have historically been set by charter-mandated formulas that have been altered periodically in municipal elections. For example, in accordance with the city's "craft pay" formula, from 1945 through 1975 city craft workers' hourly wages were set equal to the hourly wages received by unionized craft workers in the private sector in San Francisco. Reliance on charter pay formulas to set city employee pay ensured that pay determination was procedurally separated from the budgetary process that set personnel and budgetary allocations. The timing of pay and budget determination also differed. Employee pay was largely determined in the spring of each

\footnotetext{
${ }^{2}$ For a detailed reporting of municipal labor costs in the city of San Francisco and a history of the institutional factors associated with those costs for the years 1945 through 1976, see Harry C. Katz, "Municipal Pay Determination: The Case of San Francisco," Industrial Relations, Vol. 18, No. 1(Winter 1979), pp. 44- 58.

"The category, "miscellaneous" employees, includes all city employees who are not craft workers, police officers, firefighters, or transit drivers. Roughly two-thirds of the city's total workforce fit into this category.
}

fiscal year while budget allocations typically were not finally determined until the summer or early fall. ${ }^{4}$

Public sector labor relations in San Francisco are noteworthy because of the historical lack of either formalized bargaining or the signing of contracts between city officials and employee representatives. This pattern has precluded any direct route by which public employees or their union representatives could influence personnel or budget allocations through contract restrictions. Although city employees and their representatives often lobbied before city officials in an attempt to influence budgetary allocations, there is little evidence that their lobbying efforts ever had much effect. The fact that employee pay determination came before and was separated from the budgetary process, plus the absence of direct channels by which employees could influence budgetary allocations, make it possible to view the price of labor as an exogenous variable in our model of the city's budgetary process.

There are several channels through which changes in rates of employee compensation can affect budgetary allocations. First, changes in the absolute level of the price of labor to the city may affect the level of total city expenditures. Second, changes in relative prices of labor inputs may change interdepartment budgetary allocations. Finally, changes in absolute and relative prices of labor may alter intradepartmental allocations and change the share of expenditures in individual departments paid to labor.

With descriptive and econometric evidence we will trace the extent to which the city has utilized each of these channels in response to changing labor costs. Before proceeding to a discussion of the data, however, we will review briefly the organizational and demands models of budgeting.

\section{The Models}

The demands model argues that external forces, such as voter preferences, rather than

\footnotetext{
${ }^{4} \mathrm{~A}$ description and chronology of the budget process in San Francisco is provided in Richard Hayes, Understanding San Francisco's Budget (San Francisco: San Francisco Study Center, 1973).
} 
internal organizational pressures, are the crucial determinants of expenditures. In their crudest form, however, demands models do not specify any formal association between external factors and expenditure decisions. Absent any formal model, researchers have often attempted only to identify the correlations between such external factors as the tax base or demographic characteristics and public expenditures. ${ }^{5}$

Extensions of these simple models have attempted to formally link voter preferences and expenditure decisions. Utilizing formal voter models (most often the median-voter model), they measure income and price elasticities of the demand for public services that are analogous to demand elasticities measured for market commodities. ${ }^{6}$ Sometimes these models measure the price elasticity of demand as a "tax price" elasticity, which reflects voters' response to variations in the share of property taxes that is allegedly placed on the shoulders of business, nonresidents or other nonvoters. ${ }^{7}$ Other cross-sectional studies use variations in labor costs to measure price elasticities, although data limitations often limit attempts to measure price elasticities that arise in response to variations in the cost of producing public services across jurisdictions. ${ }^{8}$ Generally, these cross-sectional studies conclude that the demand for labor in the public sector is price inelastic.

\footnotetext{
${ }^{5}$ This literature, which is rather extensive, is surveyed in Werner Hirsch, The Economics of State and Local Government (New York: McGraw-Hill, 1970). See especially Alan Campbell and Seymour Sacks, Metropolitan America: Fiscal Patterns and Governmental Systems (New York: Free Press, 1967).

'See Theodore Bergstrom and Robert Goodman, "Private Demands for Public Goods," American Economic Review, Vol. 63, No. 3(June 1973), pp. 28096; Thomas Borcherding and Robert Deacon, "The Demand for the Services of Non-Federal Governments," American Economic Review, Vol. 63, No. 5 (December 1972), pp. 891 - 901; and Ronald Ehrenberg, "The Demand for State and Local Government Employees," American Economic Review, Vol. 63, No. 3 (June 1973), pp. 366- 79 .

${ }^{7}$ See Bergstrom and Goodman, "Private Demands for Public Goods," and John Bowman, "Tax Exportability, Intergovernmental Aid and School Finance Reform," National Tax Journal, Vol. 27, No. 2 (June 1974), pp. $163-73$.

${ }^{8}$ Variations in statewide average payroll costs are used to measure price variations in Ehrenberg, "The Demand for State . . . Employees."
}

A major flaw within the demands model is the implausibility of its assumptions. It seems inappropriate to characterize public agencies as optimizers of an abstract objective function. Nor does it appear fruitful to view the actions of public agencies as a direct expression of voter preferences. Organizational forces must be taken into account in any realistic explanation of the behavior of public agencies.

The organizational model of budgeting is based on Simon's analysis of administrative behavior. ${ }^{9}$ The model of organizational behavior has been extended to the level of individual behavior in the literature on cybernetic decision making. ${ }^{10}$ These models focus on the process of decision making within the bureaucratic hierarchy and the human mind. In this literature one finds concern for the role of standard operating procedures, rules of thumb, and the dominance of forces that place limits on the ability of actors to perform maximizing calculations.

Researchers such as Crecine, Wildavsky, and Lindblom have extended the organizational model to argue that bureaucratic behavior leads to budget outcomes that are largely derived from an incremental process. ${ }^{11}$ For national and local governments, public budget determination has been modeled as a process that involves simple linear decision rules. ${ }^{12}$ Taken at face value, these models suggest that decision makers inside the government bureaucracy do not readily respond either to external pressures or to changes in the prices of production inputs.

\footnotetext{
${ }^{9}$ See Herbert A. Simon, Administrative Behavior (New York: MacMillan, 1957).

${ }^{10}$ See John Steinbrunner, The Cybernetic Theory of Decision-Making (Princeton: Princeton University Press, 1974).

"See John Crecine, Government Problem Solving: A Computer Simulation of Municipal Budgeting (Chicago: Rand McNally, 1969); Aaron Wildavsky, Budgeting: A Comparative Theory of Budgetary Processes (Boston: Little, Brown, 1975); and Charles Lindblom, "The Science of 'Muddling Through'," Public Administration Review, Vol. 19 (Spring 1959), pp. $79-88$.

19. See Otto Davis, M.A.H. Dempster and Aaron Wildavsky, "A Theory of the Budgetary Process," The American Political Science Review, Vol. 60, No. 3 (September 1966), pp. $529-47$.
} 
Organizational models have heretofore largely ignored consideration of factors that induce changes in the rules of thumb employed by decision makers. Simple rules may guide the behavior of actors while at the same time rational factors, such as price effects, may lead to adjustments in those rules. ${ }^{13}$ Such price effects as the shift of expenditures away from departments that utilize relatively expensive labor may be an important rational adjustment present in the budgetary process.

Rather than merely speculate as to possible rational explanations for bureaucratic behavior, it is possible to test for the influence of rational factors on the bureaucratic rules. Relying on neither a rigid behavioral rule nor an elaborate rationalist explanation, a merging of the two models may provide a more accurate description of causal factors. ${ }^{14}$ We therefore test a model in which budgetary allocations are largely set by constant shares rules, but in which price effects are allowed to cause adjustments in those constant shares rules.

\section{Description of Data}

To analyze the city's response to changes in labor prices we traced personnel totals and budgetary allocations in a sample of eighteen city departments over the period $1945-76 .{ }^{15}$ The departments studied were

\footnotetext{
${ }^{13}$ For a mathematical model of behavior rules, see Roy Radner, "A Behavioral Model of Cost Reduction," The Bell Journal of Economics, Vol. 6, No. 4 (Spring 1975), pp. 196-215.

${ }^{14} \mathrm{~A}$ different sort of demands and organizational model is used to explain municipal budget data in John Jackson, "Politics and the Budgetary Process," Social Science Research, Vol. 1, No. 1 (April 1972), pp. $35-60$. Jackson's model differs from ours in that it ignores price effects in the budgetary process. For a discussion of maximization models of bureaucratic behavior, see William Orzechowski, "Economic Models of Bureaucracy: Survey, Extensions, and Evidence," in Thomas Borcherding, ed., Budgets and Bureaucrats: The Sources of Government Growth, (Durham, N.C.: Duke University Press, 1977), pp. $229-59$.

${ }^{15}$ The budget for the municipal railway (MUNI) is set differently from other department expenditures. The Public Utilities Commission-not the Board of Supervisors-sets the MUNI budget, which is strongly influenced by the availability of federal grants. For this reason we exclude MUNI from our model of depart-
}

Fire, Police, Municipal Railway (MUNI), Electricity, Sewage and Waste Treatment, Street Cleaning, Sewer Repair, Street Repair, Parks and Recreation, Assessor, City Attorney, District Attorney, Mayor, Board of Supervisors, Purchasing, Controller, Civil Service Commission, and the Public Library.

School expenditures were excluded because an independent school board-not city officials-regulates school expenditures in San Francisco. Expenditures on hospitals and welfare were also excluded because they are heavily influenced by state and federal grants and the regulations associated with those grants, and city officials therefore have limited discretion over them. In addition, capital construction expenditures were excluded from our analysis, because the city's capital expenditures on construction are listed in a separate city budget in a manner that makes it impossible to allocate the expenditures to particular departments.

City expenditures on items other than schools, hospitals, welfare, and capital construction compose a "discretionary" component of the city's budget. It is this discretionary city budget that is the focus of our analysis. In 1976, the total city budget in San Francisco was $\$ 734.1$ million; ${ }^{16}$ the discretionary city budget was $\$ 298.8$ million or 40.7 percent of the total. In terms of personnel, however, the departments included in the discretionary city budget are much more important, making up 66 percent of the permanent employees funded by the total city budget in 1976. ${ }^{17}$

ment appropriations. (We do, however, include MUNI in our observation of department personnel totals in Table 1.)

${ }^{16} \mathrm{We}$ excluded public service enterprise expenditures, such as the airport, water district and the port, from our calculation of the total city budget. The total city budget figure is taken from the "Annual Appropriations Ordinance, 1976," Board of Supervisors, San Francisco City and County. This document is available from the Board of Supervisors' office.

${ }^{17}$ This figure was derived in the following manner. In 1976 there were 23,785 total permanent city employees. From this figure we subtracted 1,689 employees working in public service enterprises to derive the number of employees funded by the total city budget $(22,096)$. There were 7,596 employees in the school, welfare, and hospital departments combined. Sub- 
Expenditures in the departments included in our budget model include roughly 65 percent of the discretionary city budget: the other 35 percent was excluded from our analysis in order to simplify the collection and interpretation of the data. Departments were excluded when either their structure or jurisdiction drastically changed over the thirty-two-year period of the analysis. An example is the Public Works Department, which was continually reorganized throughout the 1950s and 1960s, with separate Public Works Accounts, General Office, and Administrative Departments eventually being established.

\section{Department Employment Trends}

To analyze the city's response to changes in the prices of labor inputs, we begin with a listing of the number of permanent employees through the period 1945 - 76 in each department included in our study (see Table 1). These numbers are derived from figures presented in the annual "Salary Ordinance," which is approved by the Board of Supervisors (BOS)..$^{18}$

It is a major deficiency of the figures presented in Table $\mathbf{l}$ that they exclude temporary employees; but accurate counts of either total or department temporary city employees are difficult, if not impossible, to derive. A rough estimate is that there were 4,000 temporary workers in 1976 when total permanent city employment was $22,096 .{ }^{19}$ Many temporary employees hold jobs that are temporary in nature, such as assistants in the library or seasonal clerical workers in the assessor's office. Some, however, serve as direct substitutes for permanent employ-

tracting them left 14,500 employees in the discretionary city budget, or $66 \%$ of the employees funded by the total city budget.

${ }^{18}$ These figures are the number of approved permanent employees. Some of these approved slots are vacant because they are not budgeted positions. Others are vacant only on a temporary basis, from retirement or quits. Unfortunately, there is no way to determine the actual number of budgeted permanent employees in each department.

${ }^{19}$ Frank Levy and Michael Wiseman estimate that there were 3,764 temporary full-time employees in 1972. See "An Expanded Public-Service Employment Program: Some Demand and Supply Considerations," Public Policy, Vol. 23, No. I (Winter 1975), pp. 105 - 34, esp. p. 114. ees. ${ }^{20}$ Because the exact number of temporary workers in each department could not be included in Table 1 , the figures there must be interpreted as approximations of personnel trends in city departments.

The figures in Table 1 reveal a striking trend. The number of employees in departments $10-18$ grew rapidly in comparison to the number of employees in departments 1-9. Most of the employees in the latter group are craft workers, police officers, firefighters, or transit drivers; most of those in the former, on the other hand, are other types of city employees- "miscellaneous." In other words, Table 1 reveals a shift in favor of the employment of miscellaneous workers relative to craft workers, police officers, firefighters, and transit drivers. Aside from temporary fluctuations, the employment of craft workers, police officers, firefighters, and transit drivers has been either stable or decreasing in all departments since 1955. In departments that utilize a mix of miscellaneous and craft workers, police officers, or transit drivers (such as the Police, MUNI, and Parks and Recreation Departments), there has been a strong shift in favor of the employment of miscellaneous personnel; the Fire Department stands out as an exception to this trend, perhaps because firefighter job tasks cannot be transferred to miscellaneous employees.

As previously noted, substantial increases occurred during this period in the wages and pensions of police officers, firefighters, transit drivers, and craft workers relative to those received by miscellaneous city employees. The rapid growth in the number of miscellaneous employees relative to the number of police officers, firefighters, transit drivers, and craft workers thus provides evidence of inter- and intra-department substitution in response to changes in the relative price of labor. The Police Department supplies a striking example of the city's response to high labor costs. Throughout the entire post-World War II period there has been a large increase in the crime

\footnotetext{
${ }^{20}$ Levy and Wiseman (Ibid., pp. 113 - 14) suggest that temporary employees are utilized to avoid the retirement and health costs of permanent positions and to provide patronage by avoiding civil service regulations.
} 
Table 1. Number of Permanent Employees

in Various Departments, 1945 - 76.

\begin{tabular}{|c|c|c|c|c|c|c|c|}
\hline Department & 1945 & 1950 & 1955 & 1960 & 1965 & 1970 & 1976 \\
\hline \multicolumn{8}{|l|}{ 1. Fire } \\
\hline Firefighters & 1385 & 1700 & 1689 & 1639 & 1622 & 1710 & 1652 \\
\hline Miscellaneous & 41 & 46 & 56 & 51 & 51 & 51 & 45 \\
\hline \multicolumn{8}{|l|}{ 2. Police } \\
\hline Police officers & 1404 & 1793 & 1806 & 1821 & 1790 & 1918 & 1758 \\
\hline Miscellaneous & 70 & 74 & 98 & 112 & 245 & 526 & 499 \\
\hline \multicolumn{8}{|l|}{ 3. MUNI. } \\
\hline Drivers & 3564 & 2548 & 2028 & 1950 & 1925 & 1849 & 1862 \\
\hline Miscellaneous & 1176 & 1194 & 1086 & 961 & 944 & 894 & 945 \\
\hline 4. Electricity & 61 & 72 & 102 & 108 & 111 & 110 & 114 \\
\hline 5. Sewage \& waste treatment & - & 92 & 102 & 106 & 102 & 106 & 105 \\
\hline 6. Street cleaning & 330 & 333 & 333 & 333 & 350 & 349 & 283 \\
\hline 7. Sewer repair & 110 & 118 & 104 & 108 & 109 & 110 & 99 \\
\hline 8. Street repair & 113 & 158 & 181 & 198 & 181 & 203 & 176 \\
\hline \multicolumn{8}{|l|}{ 9. Parks and recreation } \\
\hline Craft workers & 395 & 405 & 396 & 440 & 434 & 447 & 400 \\
\hline Miscellaneous & 239 & 235 & 276 & 327 & 335 & 341 & 332 \\
\hline 10. Assessor & 87 & 124 & 141 & 138 & 141 & 133 & 128 \\
\hline 11. City attorney & 32 & 40 & 51 & 62 & 59 & 61 & 72 \\
\hline 12. District attorney & 47 & 52 & 56 & 62 & 62 & 85 & 130 \\
\hline 13. Mayor & 21 & 24 & 24 & 24 & 30 & 35 & 39 \\
\hline 14. BOS (staff only) & 15 & 15 & 15 & 17 & 16 & 29 & 51 \\
\hline 15. Purchasing & 50 & 60 & 71 & 78 & 109 & 108 & 96 \\
\hline 16. Controller & 104 & 119 & 124 & 135 & 136 & 232 & 228 \\
\hline 17. Civil Service Commission & 43 & 47 & 47 & 56 & 59 & 88 & 91 \\
\hline 18. Public library & 128 & $\underline{155}$ & 156 & $\underline{164}$ & 261 & 290 & 276 \\
\hline Total of departments listed & 9345 & 9404 & 8840 & 8890 & 9072 & 9675 & 9381 \\
\hline Total of entire City ${ }^{a}$ & 13,998 & 15,143 & 15,401 & 15,949 & 17,186 & 20,574 & 22,096 \\
\hline
\end{tabular}

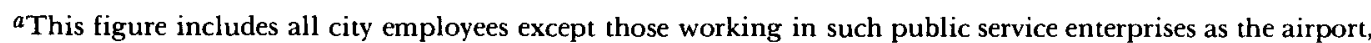
water district, and the port. Except for a few craft workers, all city employees that work in departments other than the 18 included in our sample are miscellaneous employees. By including the police, fire, and MUNI departments in our sample, we oversample departments that contain employees other than miscellaneous personnel. Given this oversampling of nonmiscellaneous personnel, the fact that total employment in departments 1 through 18 is falling over time as a fraction of total city employment is further evidence of the relative increase in the number of miscellaneous employees that occurred in San Francisco over the post-World War II period.

Source: Figures are from the annual "Salary Ordinance" by the Board of Supervisors, San Francisco City and County, for $1945-76$. 
rate in San Francisco. ${ }^{21}$ Clearly, demand pressures should have led to a large increase in the number of police officers. From 1950 to 1970 , growth did occur in the number of police officers, though not on the scale one might have expected. ${ }^{22}$ The number of police officers grew 7 percent (from 1793 to 1918) over this twenty-year period; yet total permanent employment in the city grew 36 percent (from 15,143 to 20,574). From 1970 to 1976, the number of police officers decreased sharply, bringing the size of the police force in 1976 to slightly below the 1950 figure. This $1970-76$ reduction in numbers coincides with the sharp increases in pension benefits received by police during those years. ${ }^{23}$ The overall stability in the size of the police force from 1950 to 1976 , in spite of increased demand, coincides with the large absolute and relative increases that occurred in the price of police officers over this period.

The growth in the number of miscellaneous employees working in the Police Department from 1950 to 1976, however, provides clear evidence of the increased demand for police services during those years. Apparently, rather than hire expensive police officers to meet that demand, the city increasingly hired relatively inexpensive miscellaneous (civilian) employees. ${ }^{24}$

tracting them left 14,500 employees in the discretionary city budget, or $66 \%$ of the employees funded by the total city budget.

${ }^{21}$ As an example of the increasing crime rate, from 1945 to 1974 the number of murders in San Francisco increased $260 \%$ (from 49 to 180 ). Over the same period the number of robberies increased $194 \%$ (from 1511 to 4436). See Federal Bureau of Investigation, "Number of Offenses Known to the Police," Uniform Crime Reports, (Washington, D.C.: F.B.I., 1945), Table 37, and (1974), Table 6.

${ }^{22}$ In this comparison 1950 is taken as the starting point because factors associated with the war effort depressed the number of police officers in 1945.

29From 1970 to 1976 the city's pension contribution per payroll dollar for police increased $172 \%$ (from 27.24 to 73.94). See Harry C. Katz, The Impact of Public Employee Unions on City Budgeting and Employee Remuneration-A Case Study of San Francisco (forthcoming, Garland Publishing).

${ }^{24}$ For example, in 1976 the annual base salary and pensions cost of a patrolman in the police force were $\$ 33,930$ while those of miscellaneous employees in the police department were $\$ 13,390$. The base salary is the annual salary employees receive after working for the
The substitution of miscellaneous employees for police officers took many forms in a variety of traffic, clerical, and administrative duties.

Evidence of the city's response to changes in labor costs is also provided in the Street Cleaning Department. Employment in that department is largely made up of streetsweepers. In 1972, streetsweepers were reclassified from miscellaneous to craft pay status, a change that caused a large jump in their wages. ${ }^{25}$ From 1972 to 1973 , alone, they increased $\$ 2,000$-from $\$ 11,300$ to $\$ 13,300$ a year. The city responded by sharply reducing the number of streetsweepers, even resorting to layoffs. In 1972 , the number of streetsweepers stood at 192 and total department employment was 346 employees. By 1976, there were only 144 streetsweepers and 283 total employees in the Street Cleaning Department.

\section{Department Expenditures}

The number and mix of personnel throughout city departments appear to have been adjusted in response to changes in the relative prices of labor. But the question remains whether these adjustments have been guided by an interdepartment allocation process that has itself responded to changes in the prices of labor. As mentioned earlier, the price of labor to the city government of San Francisco is derived in wageand pension-setting procedures that are separate from the procedures that set department budgetary appropriations. Therefore, if we can model the budgetary appropriations process, we can speak of the personnel figures as an outcome of the appropriations and pay-setting procedures.

We model department appropriations as a product of a constant-shares allocation rule with adjustments to that rule in response to changes in the relative prices of labor used in each department. Equation 1 is our model of departmental appropriations.

city for three years. Police officers receive higher salaries only upon promotion to higher ranks.

${ }^{25}$ For a description of the legal and political events that surrounded that reclassification, see Katz, The Impact of Public Employee Unions, p. 44. 
(1) $X_{i, t}=\left(\alpha_{1}+\alpha_{2} \quad \triangle W R P R L B_{i}\right) \cdot X_{i, t-1}$ $+\left(\alpha_{3}+\alpha_{4} \Delta W R P R L B_{i}\right) \cdot \Delta T O D E X$

where:

$$
\frac{X_{i, t-1}}{\text { TODEX }_{t-1}}+u_{i, t}
$$

$x_{i, t}=$ appropriations in departments $i$ in year $t ; 26$

$\triangle W R P R L B_{i}=$ the percentage change between years $t$ and $t-1$ in the ratio of department $i$ 's price of labor (wage and pension costs) and the average price of labor used by the city, weighted by the share of department $i$ 's expenditures that are paid to labor in year $t-1 . .^{27}$ The larger is labor's share of a department's expenditures, the more will a relative price adjustment affect that department's expenditures. To account for this, the variable $\triangle W R P R L B_{i}$ is computed by weighting the percentage change in department $i$ 's relative price of labor by the share of department $i$ 's expenditures paid to labor;

$T O D E X_{t}=$ the total discretionary budget in year $t . \triangle T O D E X$ is the change in the total discretionary budget between years $t$ and $t-1$; and

$u_{i, t}$ is an error term.

Our model distinguishes between the treatment of a base level department appropriation of funds used to continue the previ-

\footnotetext{
${ }^{26}$ Department expenditure data are taken from the Board of Supervisors, Annual Appropriations Ordinance, San Francisco City and County, various years. These figures represent annual appropriated budgets. For a sample of departments we were able to compare actual expenditure data with appropriated budgetsthey rarely differed by more than $5 \%$. Appropriations include salaries for temporary workers, and although we were unable to identify the number of temporary employees, we did pick up payments to temporary employees in our analysis of department expenditures.

${ }^{27}$ The department price of labor was computed as the sum of average wage costs and pension costs. Pension costs per payroll dollar were taken from the Employees Retirement System-Annual Report 1976 77. Average wage costs were computed as a weighted average of the number of employees in each job title times the maximum base salary for each job title. The number of employees in each job title and the maximum base salary for each job title were derived from figures in the Board of Supervisors, (annual) Salary Ordinance, San Francisco, various years. These documents are available from the Board of Supervisors' office.
}

ous year's level of department expenditures, and the treatment of new funds made available by an increase in the total discretionary budget. The sum $\left(\alpha_{1}+\alpha_{2} \Delta W R P R L B_{i}\right)$ measures the extent to which expenditures in department $i$ in year $t$ are set by continuing the previous year's expenditure level of department $i$. If a constant-shares allocation rule guides the allocation process, then coefficient $\alpha_{1}$ will be equal to one. If the base-level appropriation of department $i$ is reallocated away from department $i$ when that department's relative price of labor increases, then coefficient $\alpha_{2}$ will be less than zero.

If a constant-shares allocation rule is in effect, then department $i$ would receive a constant share of the increase in the total discretionary budget. The variable $\Delta T O$ $D E X$ (the change in the total discretionary budget between years $t$ and $t-1$ ) times

$\frac{X_{i, t-1}}{T O D E X_{t-1}}$ (department $i$ 's share of the total

discretionary budget in year $t-1)$ measures the amount by which department $i$ 's expenditures would increase if department $i$ received its full share of the increase in the total discretionary budget. Therefore, if a constant-shares allocation rule is in effect, coefficient $\alpha_{3}$ will be equal to one.

Coefficient $\alpha_{4}$ measures how much of the increase in the total discretionary budget is allocated in response to changes in relative labor prices. If increases in the total budget are allocated away from departments whose relative price of labor has increased, then coefficient $\alpha_{4}$ will be less than zero.

Estimation of Equation 1 poses two econometric problems. First, the equation contains heteroskedastic error terms. Second, if serial correlation is present in the equation, then estimates of the coefficients will be biased by the correlation between these serially correlated error terms and the lagged department variable, which is included as an independent variable. Let us assume that the error term in Equation 1 is proportional to the size of the department $\left(u_{i, t}=e_{i, t} \cdot X_{i, t-1}\right) .^{28}$

\footnotetext{
${ }^{28} \mathrm{~A}$ potential avenue for further research is specification of an error components model that would identify time- and department-specific components of the error term in Equation 2.
} 
We can then avoid both of these econometric problems by dividing through by $X_{i, t-1}$ in Equation 1 to derive Equation 2, the equation we actually estimate.

$$
\begin{aligned}
& \frac{X_{i, t}}{\bar{X}_{i, t-1}}=\left(\alpha_{1}+\alpha_{2} \Delta W R P R L B_{i}\right)+ \\
& \left(\alpha_{9}+\alpha_{4} \Delta W R P R L B_{i}\right) \cdot \frac{\Delta T O D E X}{T O D E X_{t-1}}+e_{i, t}
\end{aligned}
$$

The results of the estimation are:

$$
\text { (3) } \begin{aligned}
\frac{X_{i, t}}{X_{i, t-1}}= & 1.043+.348 \Delta W R P R L B_{i}+ \\
& (.006)^{* *}(.159)^{*} \\
(.385- & \left..784 \Delta W R P R L B_{i}\right) \cdot \frac{\Delta T O D E X}{T O D E X_{t-1}} \\
(.073)^{* *} & (1.414)
\end{aligned}
$$

$\mathrm{R}^{2}=.13 ; \mathrm{DW}=1.94$

The number in parentheses under each coefficient is its standard error.

The equation was adjusted for first-order serial correlation using an iterative Cochrane-Orcutt technique.

*Coefficient is significantly different from 0 at the .05 level (two-tailed significance test).

**Coefficient is significantly different from 0 at the .01 level.

Equation 3 is a pooled time-series and cross-section regression. It was estimated using ordinary least squares for our sample of seventeen departments for the years 194576. The constant term in Equation 3 is equal to 1.043. Of interest to us is the fact that this coefficient is significantly different from 1 at the one percent level. This means that in addition to merely continuing the previous year's level of expenditures, department expenditures increase at a 4 percent trend rate. The fact that $\hat{\alpha}_{3}$ is .385 and is significantly greater than zero implies that, along with the trend growth in department expenditures, a large fraction ( 38.5 percent) of the increase in the total discretionary budget is allocated on the basis of the department's previous share of the total budget.

The positive and statistically significant coefficient $\left(\hat{\alpha}_{2}\right)$ on the first relative labor price variable implies that increases in the relative price of previously budgeted employees are being funded with increased department appropriations. In contrast, the coefficient $\left(\hat{\alpha}_{4}\right)$ on the second relative labor price variable is negative. This implies that increases in the total discretionary budget are allocated away from departments whose relative price of labor has increased. However, $\hat{\alpha}_{4}$ is not statistically different from zero, and so this result must be interpreted with caution.

Our budget model asserts that a distinction can be made between the treatment of a department's base-level appropriation, which is merely a continuation of the department's previous year's level of expenditures, and the treatment of new funds that arise from an increase in the total discretionary budget. To test this hypothesis we estimate a version of Equation 2 in which $\alpha_{1}$ and $\alpha_{3}$ are constrained to be equal and $\alpha_{2}$ and $\alpha_{4}$ are constrained to be equal. This constrained equation does not allow for differential treatment of base level and new funds. Utilizing an $F$ test we find that the unconstrained equation (Equation 3) performs better than the constrained equation in explaining changes in department expenditures at the one percent level of significance where $F=34>F_{.01}(2,506)=4.6$.

Two conclusions can be drawn from these econometric results. First, a constant-shares allocation rule appears to influence department appropriations substantially. Second, new funds provided by an increase in the total discretionary budget are allocated away from those departments whose relative price of labor has increased, while funds that are used to continue a past (or base) level of department expenditures are not reallocated in response to price effects.

Departments can alter their labor costs in two ways: change the number or type of personnel. The possibility of alteration of the mix of employees in a department suggests that it is somewhat inaccurate to speak as though the price of labor functions as an exogenous variable in the determination of department allocations. Given that departments can change their price of labor by changing their mix of employees, the causality between a department budget and the department relative price of labor goes both 
ways. Derivation of a more precise measure of the relative price elasticity of department expenditures would require estimation of a system of simultaneous equations. However, almost all of the departments that we studied utilize essentially one type of labor, either miscellaneous employees, police officers, firefighters, transit drivers, or craft workers. Consequently, ignoring the causality going from department expenditures to the relative price of department labor probably did not seriously bias our estimate of the relative price adjustment.

\section{Department Shares}

Table 2 lists each department's expenditures as a share of the total discretionary budget. The figures illustrate the stability of department shares. Departments $10-18$ are relatively small departments; hence their expenditures and shares are more unstable.

The Police Department again serves as a useful example of the overall trend. From 1945 to 1976, the Police Department's share of the total discretionary budget rose 12.7 percent (from 18.9 to 21.3). This modest growth occurred in the face of a large increase in crime rates and presumably a sharp increase in the demand for police services.

We can now see the sources of the large increase in the number of miscellaneous personnel. Departments for which the relative price of labor was falling generally continued to receive their normal share of the increase in the total city budget. To consume their share of the budget increase,

Table 2. Department Expenditures as Percentage Share of the Total Discretionary Budget, $1945-76{ }^{a}$

\begin{tabular}{|c|c|c|c|c|c|c|c|}
\hline Department & 1945 & 1950 & 1955 & 1960 & 1965 & 1970 & 1976 \\
\hline 1. Fire & 21.8 & 21.0 & 20.6 & 20.0 & 18.0 & 17.8 & 17.3 \\
\hline 2. Police & 18.9 & 20.4 & 21.0 & 20.8 & 20.2 & 21.8 & 21.3 \\
\hline 4. Electricity & 1.0 & .9 & 1.1 & 1.4 & 1.6 & 1.2 & 1.1 \\
\hline 5. Sewage \& Waste Treatment & - & 1.9 & 1.7 & 1.6 & 1.4 & 1.8 & 2.4 \\
\hline 6. Street Cleaning & 3.3 & 3.5 & 3.4 & 3.5 & 3.3 & 2.7 & 2.4 \\
\hline 7. Sewer Repair & 1.7 & 1.8 & 1.4 & 1.4 & 1.3 & 1.2 & 1.1 \\
\hline 8. Street Repair & 2.0 & 2.4 & 2.1 & 2.2 & 1.9 & 1.9 & 1.6 \\
\hline 9. Parks \& Recreation & 8.4 & 7.3 & 7.1 & 8.0 & 9.4 & 8.5 & 7.2 \\
\hline 10. Assessor & 1.8 & 2.0 & 1.9 & 1.8 & 1.6 & 1.4 & 1.1 \\
\hline 11. City Attorney & .8 & .8 & .8 & 1.0 & .9 & .8 & .9 \\
\hline 12. District Attorney & 1.0 & .9 & .9 & .9 & .8 & .9 & 1.3 \\
\hline 13. Mayor & .5 & 6 & .4 & .3 & .5 & .5 & .4 \\
\hline 14. Board of Supervisors & .7 & .5 & .5 & .5 & .4 & .5 & .6 \\
\hline 15. Purchasing & 1.0 & .8 & .7 & .8 & 1.0 & .9 & .8 \\
\hline 16. Controller & 1.7 & 1.6 & 1.4 & 1.6 & 1.4 & 1.9 & 1.6 \\
\hline 17. Civil Service Comm. & .6 & .7 & .6 & .7 & .7 & .7 & .7 \\
\hline 18. Public Library & 1.8 & 1.6 & 1.5 & 1.7 & 1.5 & 1.2 & 1.2 \\
\hline $\begin{array}{l}\text { Other departments in the } \\
\text { discretionary city budget }\end{array}$ & 32.9 & 31.1 & 32.9 & 31.8 & 34.0 & 34.3 & 37.3 \\
\hline
\end{tabular}

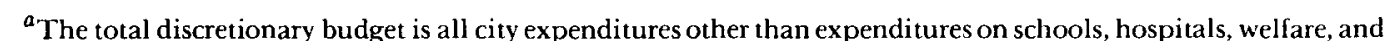
capital construction. MUNI expenditures (department 3) are excluded from our budget model for the reasons described in footnote 15.

Source: Figures are derived from data in the Annual Appropriations Ordinance, Board of Supervisors, San Francisco City and County, various years. The documents are available from the Board of Supervisors' office. 
these departments, which were utilizing relatively inexpensive labor, sharply increased their number of personnel. Conversely, those departments in which the relative price of labor was increasing, such as the Police Department, could not hire many more employees since their share of the budget was also being held roughly constant.

The dominance of constant-shares budget allocations could be interpreted as implying that budget makers possess a Cobb-Douglas utility function for department appropriations. The fraction of the total discretionary budget that determines a department's share could then be interpreted as the elasticity of that department's expenditures in the budget-maker's utility function. It is, however, unclear to us who it is that is maximizing this objective function or how they go about making the necessary maximizing calculations. Instead, we interpret the constant-shares allocation as a product of a simple decision rule that arises out of an organizational budget struggle. Concerns for equity and internal struggles within the organization are more plausible explanations of constant-shares allocations than is an omnipotent objective function. ${ }^{29}$

\section{Labor's Share of Department Expenditures}

How did intradepartment expenditures change in response to changes in the price of labor? We seek to answer this question by identifying the extent to which the city responded to increases in the price of labor by substituting capital for labor. Because we do not have a price index for capital, we cannot establish a proper estimation of any sort of production function for public services. We use, instead, the consumer price index to deflate the price of labor and derive an "absolute" price of labor $(A B P R L B)$ for each department.

Equation 4 models the determination of labor's share of the expenditures in individual departments: the dependent variable

\footnotetext{
${ }^{29} \mathrm{Greg}$ Duncan finds that the maintenance of equality of work loads guides the allocation of faculty slots within the University of California. See "Resource Allocation in a Public University: Perceived Equity and the Allocation of Faculty" (Ph.D. dissertation, University of California, Berkeley, 1976).
}

is the share of expenditures in department $i$ in year $t$ that is paid to labor. ${ }^{30}$

$$
\begin{gathered}
\text { (4) } \log \text { LBSHDE }_{i, t}=k_{i}+.147 \log A B P R L B_{i, t} \\
(.038)^{* * *} \\
-.198 \log R L P R L B_{i, t}-.003 \log F R D D E X_{i, t, t-1} \\
(.069)^{* *}(.0004)^{* *}
\end{gathered}
$$

$\mathrm{R}^{2}=.80 ; \mathrm{DW}=1.85$

The number in parentheses under each coefficient is its standard error.

This equation was adjusted for firstorder serial correlation.

** Significantly different from 0 at the 1 percent level (two-tailed significance test).

where:

$A B P R L B_{i, t}=$ the average price (wages plus pensions) of labor used in department $i$ in year $t$ deflated by the C.P.I. index for the San Francisco-Oakland SMSA for year $t ; 31$

$R L P R L B_{i, t}=$ the average price of labor used in department $i$ in year $t$ divided by the average price of labor used in the city in year $t$; and

$F R D D E X_{i, t, t-1}$ equals the difference between expenditures in department $i$ in years $t$ and $t-1$.

This equation is estimated using ordinary least squares with pooled time series and cross-section data. Observations are included for our sample of 17 departments for the years $1945-76$. The variables are all expressed in logs so the coefficients can be interpreted as elasticities. Our expenditure data only take account of operating appropriations. Nonlabor expenditures are monies spent on materials, supplies, equipment, fixed charges, and other miscellaneous items. As mentioned earlier, the city lists capital construction expenditures in a

\footnotetext{
${ }^{30}$ Labor expenditures include salaries, wages, and overtime, holiday, and differential pay.

31" C.P.I. For Urban Wage Earners and Clerical Workers, San Francisco-Oakland, 1914 - ", Series A, pamphlet (U.S. Bureau of Labor Statistics, Washington, D.C., 1977).
} 
separate budget and, consequently, those expenditures are excluded from our analysis.

The constant terms in Equation 4 are significant at the one percent level and explain almost all of the variation in labor's share. Over all departments, labor's share of department expenditures averages 82.4 percent. Equation 4 was transformed into a first difference equation and the change in labor's share was run against the change in the independent variables. With this specification the $\mathrm{R}^{2}$ dropped to .145 , verifying the importance of the constant term as an explanation of the variation in labor's share of the expenditures in individual departments. ${ }^{32}$

As with interdepartment allocations, labor's constant share of the expenditures of individual departments can be interpreted in a standard economic framework. The fact that expenditures on labor form roughly a constant share of department expenditures can be interpreted as evidence that the production function in each department is Cobb-Douglas. ${ }^{33}$ However, this conclusion is unreasonable, because CobbDouglas production functions yield constant labor's share only if labor is paid its marginal product. Research described elsewhere reveals the strong influence that noncompetitive factors exercise in the determination of municipal employee pay rates in San Francisco. ${ }^{34}$ It seems more reasonable to conclude that the stability in labor's share of the expenditures in individual departments is a product of a simple rule of

\footnotetext{
${ }^{32}$ Equation 4 was separately reestimated for departments $1-9$ and departments $10-18$. The coefficient estimates in these separate equations did not vary significantly from those reported in Equation 4. Use of a log functional form partially adjusts for heteroskedasticity and is roughly equivalent to the assumption that the error terms increase proportionately with the independent variables. No other efforts were made to adjust for heteroskedasticity in Equation 4.

${ }^{33}$ Borcherding and Deacon provide evidence of Cobb-Douglas production in the provision of nonfederal public services. One could argue, however, that their discovery of labor's constant share of expenditures is evidence of the existence of a constantshares budgetary rule. See Borcherding and Deacon, "The Demand for the Services."

${ }^{34}$ See Katz, "Municipal Pay Determination: The Case of San Francisco."
}

thumb: in order to simplify the determination of appropriate nonlabor expenditures, budget makers set nonlabor expenditures as a fixed percentage mark-up of department labor expenditures.

The positive coefficient on the absolute price of the labor variable implies that within the department, as labor's price rises, maintenance, equipment and other nonlabor expenses are postponed and labor costs are given top budgetary priority. ${ }^{35}$ Our estimate, however, is that this adjustment is small: for every one percent change in the deflated price of labor, labor's share of the expenditures in individual departments changes by only .15 percent. ${ }^{36}$

The significance of the relative price term in Equation 4 can be interpreted as evidence of a centralized budgetary process. If the Board of Supervisors merely set the department budget total and then handed the money over to the department to do with as it saw fit, then relative labor prices would not affect intradepartment expenditures. The negative coefficient on the relative price term implies, however, that as a department's labor becomes relatively more expensive, the department is forced by the Board of Supervisors to shift to a more capital-intensive production technique. Again, our estimate is that this adjustment is rather small: for every one percent increase in the relative price of department labor, we estimate a .20 percent decrease in labor's share of department expenditures. ${ }^{37}$

The negative coefficient on the change in department expenditures variable (FRDDEX) implies that departments are sluggish in their adjustments of personnel. When department expenditures abruptly

\footnotetext{
${ }^{35}$ For evidence that labor costs are given top priority in the municipal budgetary process, see Crecine, Government Problem Solving, especially pp. 74 and 203.

${ }^{36}$ This implies that for every one percent change in the deflated price of labor, the share of department expenditures going to nonlabor expenditures changes by only .68 percent.

${ }^{37}$ In a first difference version of Equation 4, the change in the relative price of labor appeared with a positive sign and the coefficient was significant at the one percent level. For this reason the negative coefficient on the relative price term in Equation 4 should be viewed with some skepticism.
} 
increase (decrease), then labor's share of the expenditures in individual departments temporarily falls (rises). This is evidence of the fact that departments are constrained in their hiring and layoff procedures. The city's reluctance to lay off employees is also revealed in Table 1 . Rarely does the number of personnel in a department decrease. Analysis of city personnel records reveals that any reductions in personnel that do occur are typically made through attrition, quits, or retirement, rather than through layoffs. Equation 3 also provides evidence of this sluggish adjustment in personnel as it reveals greater price responsiveness in new versus base-level appropriations.

Alternatively, the negative coefficient on the change in department expenditures variable in Equation 4 may be explained by the fact that nonlabor expenditures, such as equipment purchases, are "lumpy." Given a large increase in department expenditures due to an unusual expenditure on equipment, it is only natural to expect that labor's share of the expenditures in a department would temporarily decrease.

\section{Summary}

Rather than postulate maximizing behavior, as is commonly done in economic analyses of public budgeting, we use a hybrid of the organizational and demands model of budgeting to test for the influence that adjustments in response to changes in the price of labor inputs exert on budget allocations. We find that a constant shares rule, supplemented by relative price adjustments, guides interdepartment budgetary allocations. Our observations support the claims of organizational models of budgeting. A simple decision rule, in this case constant shares, appears largely to determine interdepartment appropriations.

The budget model we use allows for different treatment of a department's base-level appropriation (the continuation of the previous year's expenditure level) and the treatment of new funds made available by an increase in the total city budget. We find evidence that new funds provided by an increase in the total city budget are allocated away from those departments in which the relative price of labor has increased while a department's base-level appropriation is not reallocated in response to price effects. In an explicit test of our hypothesis that new money is treated differently from money used to continue a department's previous year's spending level, we find that the performance of our model is statistically superior to that of a model that constrains budget makers to treat all money the same.

Intradepartment expenditures also appear to be determined largely by a simple decision rule. Labor's share of the expenditures in individual departments is roughly held constant with minor adjustments in response to the price of labor. Adjustments that occur in personnel are rather sluggish. Personnel totals rarely decrease in a department because the city is reluctant to lay off employees. When personnel cuts are made, they are typically accomplished through attrition.

Previous cross-sectional analyses of state and local government expenditures have concluded that the demand for labor in the public sector is price inelastic. In contrast, we find a considerable amount of price responsiveness in the municipal budgetary process. Specifically, using longitudinal data we find considerable evidence of adjustments in personnel and appropriations in response to changes in the price of labor inputs in the provision of public services in the city of San Francisco over the postWorld War II period. In response to the rapid rise in the price of police officers, firefighters, transit drivers, and craft workers, the city essentially froze the number of such employees in a wide range of departments. This occurred even in the face of large increases in the demand for the services provided by these employees, as with police officers. Over the same period the city sub. stantially increased the number of less expensive miscellaneous employees. Longitudinal analysis of personnel trends in other cities may also discover much greater price responsiveness in public budgeting than that revealed in previous cross-sectional analyses.

To the extent the figures in Tables 1 and 2 are representative of budget and personnel trends in other cities in California, they 
may provide a partial explanation of the emergence of a "taxpayers' revolt" in California, which was signalled by the passage of Proposition 13 in June $1978 .{ }^{38}$ The figures in those tables reveal that in San Francisco over the post-World War II period there was stability in the number of highly visible (and possibly greatly desired) employees in departments 1 through 9 , such as police officers, firefighters, and street cleaners. Over the same period the number of clerical and administrative employees, who make up the bulk of personnel in departments 10 through 18 (and other city departments), was increasing substantially. Taxpayers in San Francisco witnessed a large increase in the total city budget accompanied by no increase in the number of police officers,

${ }^{38}$ This point was developed in conversations the author had with Frank Levy. firefighters, or street cleaners. It is possible that the dissatisfaction taxpayers in San Francisco and other California cities felt toward that trend contributed to the passage of Proposition 13.

An important conclusion of our research is that it is fruitful to analyze the determination of public services in a city context. Significant "economic" adjustments occurred within the San Francisco city budget. Variations in the growth of personnel across departments that arose in response to changes in the relative price of labor were an important avenue of price responsiveness in the supply of city services. Economic models typically concern themselves with the tradeoff between public and private goods, a pattern that may lead observers to ignore important economic adjustments that occur within the mix of services provided by public agencies. 
Copyright of Industrial \& Labor Relations Review is the property of Cornell University. The copyright in an individual article may be maintained by the author in certain cases. Content may not be copied or emailed to multiple sites or posted to a listserv without the copyright holder's express written permission. However, users may print, download, or email articles for individual use. 